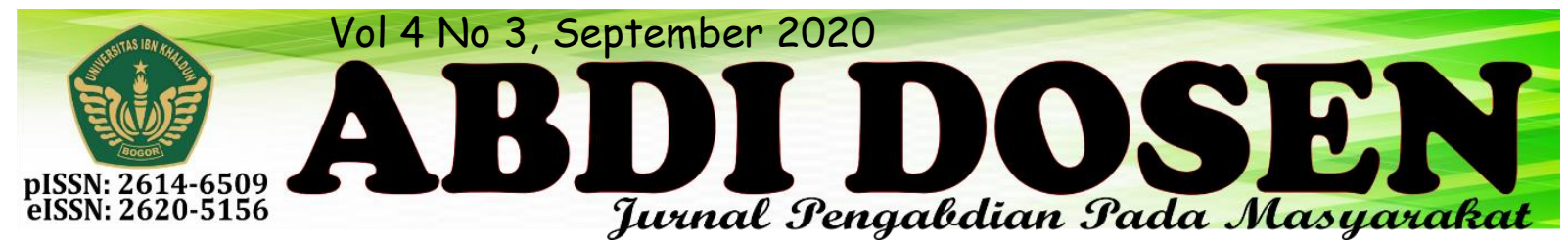

\title{
MENINGKATKAN INFRASTRUKTUR UNTUK MEWUJUDKAN STABILITAS PENDIDIKAN, KESEHATAN DAN EKONOMI STUDI KASUS DESA RENGASJAJAR
}

\author{
Ade Hendri Hendrawan ${ }^{1}$, Desty Anggie Mustika ${ }^{2}$ \\ hendri@uika-bogor.ac.id ${ }^{1}$ \\ destyaanggiemustika695429@gmail.com ${ }^{2}$ \\ Dosen Fakultas Teknik dan Sains Universitas Ibn Khaldun Bogor ${ }^{1}$, Dosen Fakultas Ekonomi dan Bisnis \\ Universitas Ibn Khaldun Bogor ${ }^{2}$
}

\begin{abstract}
ABSTRAK
Kuliah Kerja Nyata (KKN) merupakan salah satu bentuk pengabdian kepada masyarakat yang dilakukan oleh mahasiswa di daerah tertentu atau lembaga pendidikan, dilaksanakan secara kelompok. Kegiatan KKN (Kuliah Kerja Nyata) bertujuan untuk memberikan pengalaman kerja nyata di lapangan dalam membentuk sikap mandiri dan tanggung jawab dalam pelaksanaan pekerjaan di lapangan. Kegiatan KKN dibagi menjadi empat tahap kegiatan,yaitu pembekalan, pelaksaaan kegiatan di lokasi, penyusunan laporan,dan evaluasi. Pelaksanaan KKN ini dimulai dari tanggal 6 Agustus 2019 sampai dengan 6 September 2019 di Kampung Lebakwangi Hilir, Desa Rengasjajar, Kecamatan Cigudeg, Kabupaten Bogor. Program kerja di Kampung Lebakwangi merupakan program yang lebih menekankan kepada tema Pendidikan dan Pemberdayaan Desa. Program fisik kelompok 57 dan 58, antara lain: Renovasi MCK, Pengadaan Tempat Wudhu, Pengadaan Plang Jalan, Pengadaan Penerangan Jalan, Senam Sehat. Program nonfisik yang di lakukan yaitu pelaksanaan kegiatan di Madrasah Diniyah Nurul Falah, pelaksanaan kegiatan di SDN Lebakwangi 02, penyuluhan program cuci tangan, pengadaan bimbel di posko, membantu mengajar di SDN Lebakwangi 02, pelatihan membuat kerajinan tangan, sosialisasi menabung sejak dini, memperkenalkan jenis mata uang dari beberapa negara, sosialisasi dampak negatif pada penggunaan gadget (Handphone) anak usia dini (6-12), workshop kewirausahaan, berpartisipasi dalam kegiatan posyandu (Pemeriksaan kesehatan pada balita), penyuluhan PHBS (Perilaku Hidup Bersih \& Sehat), dan berpartisipasi dalam kegiatan HUT RI ke 74 dan acara perpisahan KKN.
\end{abstract}

\section{Kata Kunci : Infrastruktur, Pendidikan, Kesehatan, Ekonomi}

\section{PENDAHULUAN}

\section{Latar Belakang}

Kuliah Kerja Nyata (KKN) merupakan proses pembelajaran mahasiswa melalui berbagai kegiatan langsung ditengah-tengah masyarakat, dan mahasiswa berupaya untuk menjadi bagian dari masyarakat serta secara aktif dan kreatif terlibat dalam dinamika yang terjadi di masyarakat. Keterlibatan mahasiswa bukan saja sebagai kesempatan mahasiswa belajar dari masyarakat namun juga memberi pengaruh positif dan aktif terhadap pengembangan masyarakat sehingga memberi warna baru dalam pembangunan masyarakat. 
Fida (1997:1) menyatakan bahwa "KKN adalah salah satu bentuk kegiatan pengabdian kepada masyarakat oleh Perguruan Tinggi yang dilakukan oleh mahasiswanya di bawah bimbingan dosen dan pimpinan pemerintah daerah". Pengertian pengabdian kepada masyarakat ialah pengalaman ilmu pengetahuan, teknologi dan seni yang dilakukan oleh Perguruan Tinggi secara ilmiah dan melembaga langsung kepada masyarakat untuk mensukseskan pembangunan dan pengembangan manusia pembangunan menuju tercapainya manusia yang maju, adil dan sejahtera berdasarkan Pancasila, serta meningkatkan pelaksanaan misi dan fungsi Perguruan Tinggi.

KKN adalah suatu bentuk pendidikan dengan cara memberikan pengalaman belajar kepada mahasiswa untuk hidup di tengah-tengah masyarakat, secara terstruktur melalui beberapa tahap diantaranya persiapan, pembekalan dan observasi sampai pada tahap evaluasi. Persiapan merupakan tahap awal sebelum KKN dilaksanakan, persiapan dilakukan agar kegiatan dapat terlaksana dengan terstruktur dan terarah sesuai rencana. Dalam pelaksanaan KKN di masyarakat, mahasiswa diharapkan dapat memberikan bantuan pemikiran, tenaga, dan ilmu pengetahuan dalam merencanakan dan melaksanakan program pengembangan Desa.

Kegiatan KKN pada dasarnya merupakan kegiatan interaksi sosial yang melibatkan berbagai pihak. Dalam kegiatan KKN, kita akan menjumpai berbagai bentuk interaksi sosial yang secara garis besarnya dapat diklasifikasikan ke dalam tiga pola atau bentuk interaksi sosial, yaitu : (1) interaksi antar orang perorangan; (2) interaksi antara orang dan kelompoknya, dan sebaliknya; dan (3) Interaksi antar kelompok (Gunawan, 2000:32).

KKN juga memiliki tujuan untuk meningkatkan keterampilan sosial yang sangat penting dimiliki oleh mahasiswa sebagai calon pengemban amanah untuk memajukan bangsa dan negaranya. Tanpa memiliki keterampilan sosial manusia tidak dapat berinteraksi dengan orang lain yang ada di lingkungannya karena keterapilan sosial dibutuhkan dalam hidup bermasyarakat. Menurut Indra Dermawan (2008:29) "keterampilan sosial (Social skill) adalah kemampuan individu untuk membangun hubungan secara efektif dengan orang lain, mampu mempertahankan hubungan sosial tersebut dan mampu menangani konflik-konflik interpersonal secara efektif'.

Menurut Wikipedia keterampilan sosial adalah keterampilan yang digunakan untuk berinteraksi dan berkomunikasi dengan orang lain sesuai peran dan struktur sosial yang ada.

Menurut Sjamsuddin dan Maryani (2008:6) keterampilan sosial adalah kemampuan secara cakap yang tampak dalam tindakan, mampu mencari, memilih, dan mengelola informasi, mampu memecahkan hal-hal baru yang dapat memecahkan masalah sehari-hari, memiliki keterampilan berkomunikasi, baik lisan maupun tulisan, memahami, menghargai, dan mampu bekerjasamma dengan orang lain yang majemuk, mampu mentransformasikan kemampuan akademik dan beradaptasi dengan perkembangan masyarakat.

Menurut Mu'tadin dalam Sugeng Priyanto (2008:122) keterampilan sosial adalah kemampuan atau kecakapan yang dimiliki seseorang untuk menyesuaikan diri dan berinteraksi dengan lingkungannya yang meliputi kemampuan berkomunikasi, 
menjalin hubungan dengan orang lain, menghargai diri sendiri dan orang lain, memberi dan menerima kritik yang diberikan orang lain.

Maka Kuliah Kerja Nyata sangat diperlukan mahasiswa untuk mengembangkan potensi dirinya berupa ilmu yang didapat di bangku kuliah untuk kemudian diaplikasikan lewat kemampuan keterampilan sosial yang diasah selama kegiatan tersebut berlangsung.

\section{Analisis Situasi}

Kuliah Kerja Nyata (KKN) merupakan bentuk kegiatan pengabdian kepada masyarakat yang bersifat khusus, karena dalam KKN darma pendidikan dan pengajaran, penelitian serta pengabdian kepada masyarakat dipadukan ke dalamnya dan melibatkan sejumlah mahasiswa serta sejumlah staf pengajar ditambah unsur masyarakat.

Kampung Lebakwangi Hilir merupakan merupakan salah satu kampung yang terletak di Desa Rengasjajar, Kecamatan Cigudeg, Kabupaten Bogor. Sebagian besar wilayah di kampung ini adalah persawahan, pertambangan dan perkebunan sawit. Masyarakat desa Rengasjajar pada umumnya merupakan buruh tani, pedagang dan buruh swasta. Melihat dari mata pencaharian masyarakat dan kegiatan sehari-hari dapat disimpulkan bahwa potensi dari Desa Rengasjajar adalah pada bidang pertanian dan perkebunan. Jika bidang ini dapat dikembangkan maka akan menjadi sangat potensial bagi masyarakat desa setempat.

\section{Potensi dan Permasalahan Desa}

\section{Rengasjajar}

a. Sosial Ekonomi dan Budaya Masyarakat

Desa Rengasjajar memiliki kurang lebih 12.640 jiwa. Mayoritas mata pencaharian warga desa
Rengasjajar adalah buruh tani,

sebagian nya lagi pedagang dan buruh swasta.

b. Bidang Pendidikan

- Kurangnya metode pengajar, media dan sarana prasarana.

- Rata-rata latar pendidikan masyarakat hanya sampai tingkat SMP dan SMA

c. Bidang Kesehatan

- Kurangnya kesadaran warga dalam menjaga kebersihan lingkungan

- Kurangnya pasokan air bersih

- Kurangnya udara bersih akibat tercemar oleh pertambangan di desa

d. Bidang Ekonomi

- Tingkat perekonomian masyarakat masih rendah.

- Kurangnya minat dari warga untuk berwirausaha.

e. Bidang Agama Islam

- Kurangnya pemahaman agama

f. Bidang Teknik

- Kurangnya pengetahuan teknologi

- Minimnya penerangan jalan

\section{Solusi}

a. Bidang Pendidikan

- Dalam bidang pendidikan telah mengaplikasikan metode pembelajaran yang sesuai di SDN Lebakwangi 02 dan di Madrasah Diniyah Nurul Falah.

- Membuka Bimbingan Belajar bagi anak-anak di kampung lebakwangi hilir.

b. Bidang Kesehatan

- Dalam bidang kesehatan megadakan penyuluhan PHBS (cara mencuci tangan yang baik dan benar) di SDN Lebakwangi 02.

- mengadakan kegiatan Minggu Bersih di lingkungan Kampung Lebakwangi Hilir.

- berpartisipasi dalam kegiatan posyandu (Pemeriksaan kesehatan pada balita). 
c. Bidang Ekonomi

- Dalam bidang ekonomi kami mengadakan sosialisasi menabung sejak dini.

- Pelatihan Kewirausahaan

d. Bidang Agama Islam

- Dalam bidang agama islam kami menghidupkan kembali kegiatan pengajian rutin masyarakat.

- Mengikuti rutinitas kegiatan agama masyarakat setempat.

\section{METODE PENGABDIAN}

\section{Metode Pendekatan}

1. Pendekatan Religius

Yaitu pendekatan yang menggunakan nilai-nilai agama sebagai basis kegiatan.

\section{Pendekatan Organisasi}

Organisasi merupakan hal yang memiliki peran penting di tengah-tengah masyarakat. Pendekatan organisasi di lakukan untuk mempermudah pengenalan kami kepada warga Desa Rengasjajar Kampung Lebakwangi Hilir. Karena suatu himpunan dapat menjadi tolak ukur penilaian terhadap anggota yang tergabung di dalamnya.

\section{Pendekatan Sosial}

Pendekatan ini dilakukan agar mudah berinteraksi, berdiskusi dan berbaur dengan masyarakat setempat. Agar program yang dijalankan dapat dibantu serta bekerjasama sesuai dengan kamampuan masing-masing.

4. Pendekatan Edukasi

Desa Rengasjajar Kampung Lebakwangi Hilir memiliki masyarakat yang mempunyai latar belakang yang berbeda-beda. Tidak semua masyarakat
- Meningkatkan pemahaman keagamaan di Madrasah Diniyah Nurul Falah.

e. Bidang Teknik

- Dalam bidang teknik mensosialisasikan dampak negatif pada penggunaan gadget (Handphone) anak usia dini (612) untuk warga Kampung Lebakwangi Hilir.

- Menyampaikan pengetahuan beberapa teknologi

- Mengadakan penerangan jalan

mempunyai pengetahuan yang lebih modern dalam menjalankan kehidupan sehari-hari di lingkungannya. Maka dari itu pendekatan edukasi sangatlah di perlukan untuk mempermudah pendekatan dan pengenalan program kami kepada warga.

\section{Pendekatan Partisipatori}

Pendekatan ini berorientasi pada upaya peningkatan peran langsung dari peserta KKN dalam proses dan pelaksanaan kegiatan.

\section{Langkah Evaluasi}

1. Evaluasi proses, yakni evaluasi yang terkait dengan perencanaan serta pelaksanaan kegiatan. Evaluasi proses akan dilakukan setiap hari oleh seluruh anggota kelompok KKN 57 dan 58.

2. Evaluasi hasil, yakni evaluasi yang akan dilaksanakan setelah kegiatan berlangsung. Evaluasi hasil ditujukan untuk menguji pemahaman warga, yang sudah pernah disosialisasikan oleh mahasiswa KKN kelompok 57 dan 58 Universitas Ibn Khaldun Bogor. 


\section{HASIL DAN PEMBAHASAN}

Ada berapa program yang kami lakukan diantaranya :

\section{1) Bidang Pendidikan}
a. Pengembangan Madrasah Diniyah
b. Bimbingan Belajar
c. Mengajar di SDN Lebakwangi 02

\section{2) Bidang Ekonomi}

a. Mengadakan Sosialisasi Menabung Sejak Dini

b. Sosialisasi Memperkenalkan JenisJenis Mata Uang

\section{3) Bidang Kesehatan}
a. Penyuluhan Kesehatan Prilaku hidup bersih dan sehat (PHBS)
b. Penyuluhan cara mencuci tangan yang baik dan benar
c. Senam Sehat

d. Pendampingan Posyandu

e. Perilaku hidup bersih dan sehat merupakan seperangkat perilaku manusia yang dibangun dan dikembangkan dalam kehidupan sehari - hari.

\section{4) Bidang Teknik}

a. Sosialisasi dampak penggunaan gadget pada anak - anak

\section{5) Bidang Agama Islam}

a. Mengajar di Madrasah Diniyah Nurul Falah.

b. Pengajian Rutin

6) Program Unggulan

a. Renovasi MCK \& Pengadaan Tempat Wudhu

b. Pengadaan Plang Jalan

c. Pengadaan Penerangan Jalan

\section{KESIMPULAN}

Berdasarkan hasil kegiatan, pengamatan, maupun pelaksanaan program kerja KKN yang telah direncanakan, disusun dan dilaksanakan. Maka kelompok 57 dan 58 KKN Tematik Terintegrasi Universitas Ibn Khaldun Bogor 2019 di Kampung Lebakwangi Hilir Desa Rengasjajar Kecamatan Cigudeg Kabupaten Bogor:

1. Terealisasinya program pengabdian kepada masyarakat Desa Rengasjajar yang dilaksanakan oleh mahasiswa dalam rangka mewujudkan program Universitas Ibn Khaldun sesuai dengan visi misi Universitas Ibn Khaldun

2. Terbentuknya building para mahasiswa dan mahasiswi yang mengikuti program KKN

3. Terbentuknya program kerjasama langsung antara mahasiswa dan masyarakat yang saling bersinergi dan saling menguntungkan
4. Meningkatkan kepedulian dan rasa empati mahasiwa kepada masyarakat sehingga terjadinya perubahan perilaku mahasiswa

5. Potensi desa di kampung lebakwangi hilir, rengasjajar cigudeg kabupaten bogor telah di kelola cukup baik oleh masyarakat, sehingga tercapai hasil yang memuaskan, diantaranya:

a Kerjasama yang baik antar Masyarakat, Perangkat desa serta instansi terkait guna memperlancar pembangunan desa.

b Perbaikan dan pemeliharan jalan sehingga dapat membuka wilayah desa yang terisolisir dan dapat memperlancar transportasi.

c Pemberdayaan swadaya masyarakat untuk menunjang pembangunan desa. 
DAFTAR PUSTAKA

(2018). Petunjuk Pelaksanaan KKN

Tematik Terintegrasi 2018

Universitas Ibn Khaldun Bogor. Bogor : UIKA Press

Dermawan, Indra. 2008. Kiat Jitu Taklukan Psikotes. Yogyakarta: Pustaka Widyatama.

Gunawan, Ary H. 2000.Sosiologi Pendidikan. Jakarta: Rineka Cipta.

Priyanto, Sugeng dkk. 2008. Contextual Teaching and Learning Pendidikan Kewarganegaraan Sekolah Menengah Pertama/Madrasah Tsanawiyah Kelas IX Edisi 4. Jakarta: Pusat Perbukuan Departemen Pendidikan Nasional.

Prasetya, E. (2018). Pemberdayaan Masyarakat Tentang Kesehatan, Pendidikan dan Kreatifitas. Abdi Dosen: Jurnal Pengabdian Pada Masyarakat 2 (1), 19-25.
Prasetya, E. (2020). 10 Characteristics of SMK Teachers in the Industrial Era 4.0 (Case Study at SMK Bina Profesi Bogor). Edumaspul: Jurnal Pendidikan, 4(1), 50-55. https://doi.org/10.33487/edumaspul.v $\underline{4 \mathrm{i} 1.297}$

Sjamsuddin, H dan Maryani, E, 2008. Pengembangan Progam Pembelajaran IPS untuk Meningkatkan Kompetensi Keterampilan Sosial. Makalah pada seminar nasional, Makassar.

Internet:

http://www.kompasiana.com/nyaiendit/me mbangun-sebuah-tamanbacaanmasyarakat_5516fd07a33311f17a $\underline{\text { ba7fc3 }}$

http://pkm.uikabogor.ac.id/index.php/ABD $\underline{\text { IDOS/iss ue/archive }}$ 